\title{
Patterns of pipe-borne water supply in the Buea Municipality: Challenges and way forward
}

\author{
Baba Adamu ${ }^{1}$, Balgah Sounders N. ${ }^{2}$, Pamboudam Nfondoum C. ${ }^{3}$ \\ ${ }^{1}$ Department of Geography, Faculty of Social and Management Sciences, University of Buea, P.O. Box 63, Buea, Cameroon \\ ${ }^{2} \mathrm{Ph} . \mathrm{D}$, Associate Profess or of Geography, Department of Geography, Faculty of Social and Management Sciences, \\ University of Buea, Cameroon \\ ${ }^{3}$ Ph.D, Department of Geography, Faculty of Social and Management Sciences, University of Buea, Cameroon
}

\begin{abstract}
A growing quest in the mind of man today is to establish a balance equation between his activities and the available freshwater. Trillion of dollars have been spent worldwide to reduce water shortages, but governments and stakeholders ubiquitously have failed to empower the city dwellers and to ambush the challenges to pipe borne water supply. In many parts of developing countries including Cameroon, population growth, urbanization and water demands are rising rapidly, whereas water availability, quality, reliability, frequency and distribution are decreasing rapidly due to planning deficiencies, inefficient management and deterioration. This study aimed at examining the patterns of pipe borne water supply in the Buea Municipality, challenges and municipal response. A sample size of 120 inhabitants was taken to represent the entire population in the study area. Simple random sampling technique was then used to identify the most appropriate respondents and locations. Findings were analyzed using Statistical Package of Social Sciences (SPSS), Microsoft excel and represented in the form of tables and figures. Findings revealed that, there is limited water supply reliability, access and distribution in the Buea Municipality attributed to physical and anthropological influences such as inadequate water supply, degradation and poor water management by the municipal authorities. The study look forward to giving recommendations of the use of water storage devices such as water tanks as a short term strategy and the extension of pipes distribution lines to be in direct proportion with population growth among others.
\end{abstract}

Keywords - Water supply, water management, urban area, water availability and accessibility, Buea municipality.

\section{INTRODUCTION}

One of the most valuable natural resources on the globe is water. Water is use for domestic, industrial, agricultural and recreational purposes. Access to freshwater resources is therefore, essential to sustain life and critical for human health and wellbeing (Moyo, 2011). Water is not a viable good per say but, rather an inheritance which must be safeguarded and protected as such (European Commission, 2002). However, due to increase demand and use for water, the availability, reliability and quality of water are crucial. There is a direct association between water, water delivery and water management (Fonjong and Fonkem, 2017). The water crisis in the $21^{\text {st }}$ Century is multi-dimensional, dynamic and above all classified among the host of problems to be faced by many societies and the world. While some authors relate this crisis to poor management (Rogers et al, (2006) and (Tuner et al, 2011), others relate it to a set of environmental problems aggravated by economic and social development quandaries (Gleick, 2000). Yet, Tuner et al. (2011) observed that the deepening intricacies of urban water supply are due to candid difficulties of availability, reliability, distribution of water supply and increased demand and to a sectorial management process that responds to problems without a logical methodology that tries to predict them.

Whatever the faculty of thought, it is imperative to note that, urban water supply has become a serious urban development quandary in many developing countries unlike the case in most developed countries where there are adequate managerial skills and government policies to salvage the situation. Although, there is no global water paucity as such, an increasing number of developing regions including Sub Saharan Africa (SSA), Middle East and North Africa (MINA) and South East Asia are chronically short of water supply (FAO, 2007).Population growth rates and rapid urbanization in most urban centers in Africa for example are leaving infrastructure service provisions such as pipe borne water supply, electricity and so on severely stretched (Pastore, 2015). As a consequence, urban water supply production, distribution and coverage have actually declined in many areas and neighborhoods in the continent. Moreover, Africa's water shortages are related to under-development of hypothetically available resources, their uneven 
distribution and mismanagement in time and space. This is coupled with an unrelenting population growth rate of $4 \%$ per year which is a major factor in on-going pipe borne water supply challenges in many urban centers. In such cases therefore, the resultant gab created by inadequate pipe borne water supply is filled by lower rate alternatives such as bore holes and wells both of which are expanding at a much faster rate than improved alternatives such as piped water and stand post. In Nigeria, Ikelegbe and Okaruwa (2007) observed that there exists an uneven distribution of pipe borne water supply among commercial, government establishments in high and low income residential areas. Also, densely populated lower income zones are served with few and widely spaced stand pipes which flow intermittently. The authors further cited the fact that,poor distribution, lack of planning and management of resources accounted for these phenomenon leaving the population with no choice but to rely on alternative water sources of poor quality wells and boreholes.

In Cameroon, water scarcity is common virtually in all urban and rural areas. In urban areas however, major constraints to pipe borne water supply include: power failures, inadequate water supply infrastructures and sources, uneven distribution, poor planning and management (Andrew et al, 2010). The water utility company (CAMWATER) is unreliable, intermittent and in most cases inaccessible to majority of the neighborhoods in major town of the country, thus giving rise to a high dependency on unsafe supplementary sources of pipe borne water supplyby the population which are susceptible to water borne diseases. The patterns of pipe borne water supply in the Buea Municipality vary widely from one settlement to another within the same town due to spontaneous residential development, level of incomes, degradation, misallocation and mismanagement and population growth. Molyko neighborhood that has experienced rapid residential development and population increase in the last four decades in the Buea Municipality faces inadequate water supply as a major challenge unlike other settlements like Federal Quarter and GRA where the severely of water scarcity is minimal due to misallocation, mismanagement, rationing by the water utility company (CAMWATER) and high demands by different domestic, economic and social activities. Whatever the case,the catchment's ability to supply pipe borne water to the various settlements at a right quantity and time continue to be a major night mere for the municipal authorities and stakeholders to solve. Therefore, the Buea Municipality residents are in dire need of adequate, accessible and reliable good quality and quantity water supply sources and facilities to sustain their domestic, industrial, recreational and agricultural needs amidst these growing challenges.

\section{THE PROBLEM}

Buea Municipality of the South West Region of Cameroon is composed of diversified residential settlement patterns, economic activities, population growth and income levels (Buea Council, 2008).Majority of economic activities, population, low class individuals, informal settlements are concentrated in the lower part of the Buea Municipality while administrative and high income residents and standard houses are concentrated in the upper part of the Buea Municipality. Like most towns and cities in Cameroon, Buea Municipality has experienced an immense increase in uncontrolled residential development and population growth in recent times (Balgah, 2009; Kimengsi, Gwan \& Elinge, 2016) thus, straining the ability of CAMWATER to adequately supply pipe borne water facilities to the different residential neighborhoods. Figures from Census Bureau of the Regional National Institute for Statistics (NIS), population studies (BUCREP, 2005) as well as United Nations (UN) growth rate for African cities put the population of the Buea Municipality at approximately 200,000 inhabitants. For instance, Molyko being the most populated residential neighborhood of over 22,000 (20\%) inhabitants in the Buea Municipality is being supplied with just $8000 \mathrm{~m}^{3}$ of water daily (less than 20 liters per person per day). This implies that there is a pressure on pipe borne water supply by the ever expanding population of students, commercial activities and hotels as well as decongestion and depletion of water sources in some neighborhoods. This is a clear indication that the demand for water for domestic, industrial agricultural and recreation purposes are not met by the water supply authorities in the Buea Municipality thereby posing a challenge to urban planners and municipal authorities. Water is not equally supply on a daily basis except in high residential settlements of Federal quarters and Government Residential Area (GRA) where majority of government officials and high income citizens resides. These settlements are considered as government priority areas in terms of service provisions in the Buea Municipality. However, in the other residential neighborhoods, water it is actually supplied after every two days and in some cases it does not flow at all due to rationing (distribution of water to different zones at different time intervals). Worse enough is the fact that in Most parts of Molyko, pipe borne water flow just for a few hours and stops when most people have not fetched water thereby pending domestic, industrial, commercial and agricultural activities. 
These quagmires in pipe borne water supply in the study area have therefore affected not only the socio-economic activities operations but also the health and wellbeing of the population as they turn to unsafe water sources like streams, wells, boreholes and rivers. In recent years however, the authorities in charge of water supply have made efforts aimed at increasing the pipe borne water supply from $13,000 \mathrm{~m}^{3}$ to $15,000 \mathrm{~m}^{3}$ per person per day. Despite all these efforts, the challenges of pipe borne water supply continue to persist in the Buea Municipality. Consequently, this study seeks to examine the access to pipe borne water supply by the Cameroon Water Utility Company (CAMWATER), to examine the patterns of pipe-borne water supply in the Buea Municipality, to examine the challenges to pipe borne water supply and proffer possible solutions for the effective pipe-borne water supply in the Buea Municipality.

\section{STUDY AREA}

The actual located of the Buea Municipality is on the Eastern foot slopes of Mount Cameroon (Map. 1): It covers a surface are of above 36,000 hectares (Conrade, 1970). Itis the former capital of German Kamerun (1901/1919), Federated State of West Cameroon (19221948), Southern Cameroon (1949-1961) and is currently the Regional Capital of the South West Region of Cameroon.
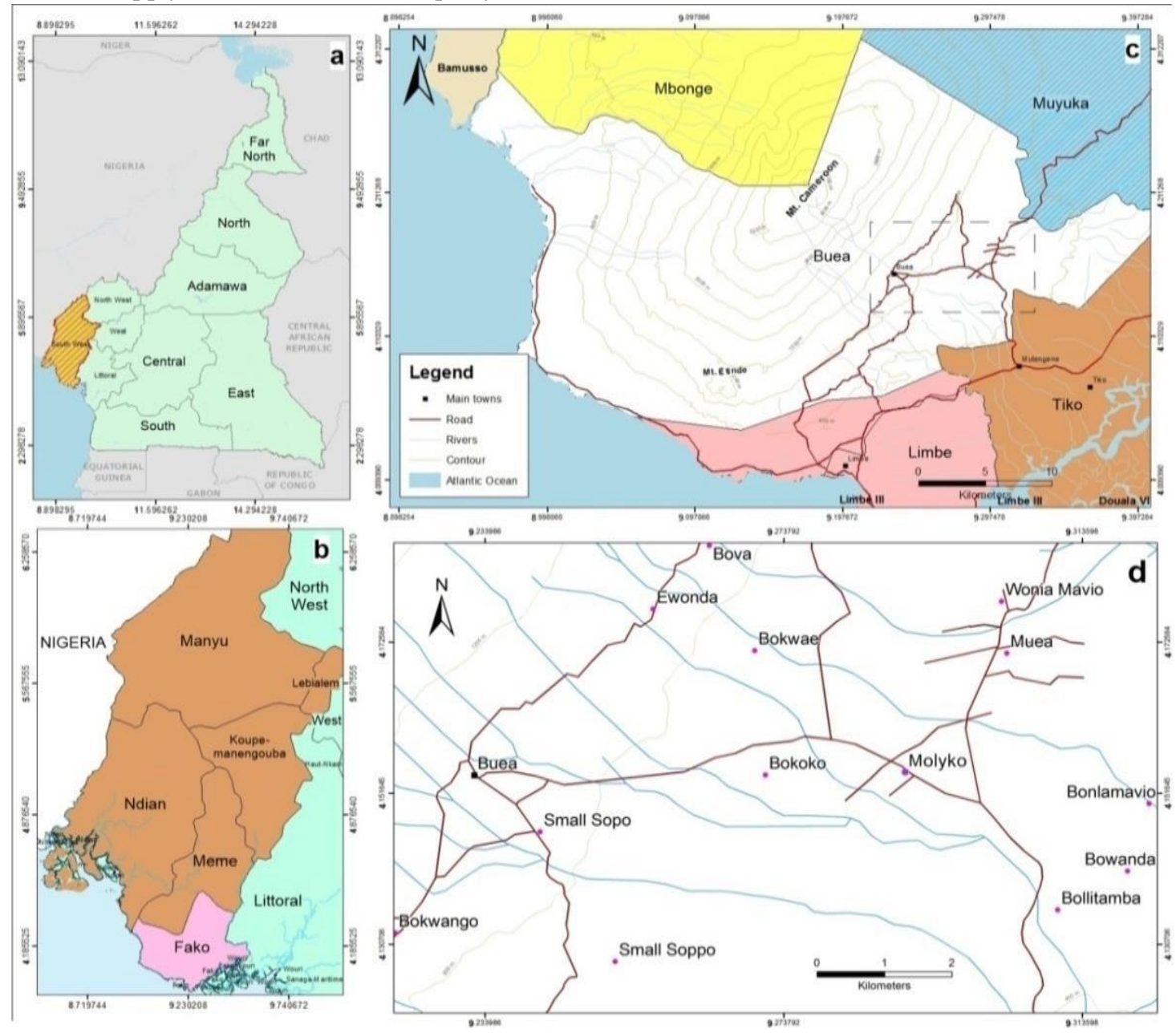

Map 1: Location of Buea Municipality in Fako Division of Southwest Region in Cameroon

Source: Kedia (2015)

The Municipality is about 915 meters above sea level. Upper elevations neighborhoods of the town like in Federal Quarters and Government Residential Area (GRA) tend to be cold and cloudy, while lower elevations like Molyko tend to be much warmer and less humid. Like in most parts of Cameroon, the Municipality experiences dry and wet seasons. Rainfall in the study area is on average much more than the rest of the country although this rainfall cannot be highly relied upon for the provision of adequate water supply in the area of study. The average temperature is mild, between $23^{\circ} \mathrm{C}$ and $25^{\circ} \mathrm{C}$ and it has an annual rainfall that varies between $114 \mathrm{~mm}$ to 1,053mm per month (Meteo.com, 2013). The population of the study area is also estimated at about 200,000 
growing at more than 5\% per annum (BUCREP, 2005) cited in (Baba and Ndi, 2017). It is also among the first five fastest growing cities in Cameroon (Baba and Ndi, 2017). Due to its historical background and location, the town forms a link for people accessing administrative, touristic, educational establishments and fertile soils for agricultural activities. These have attracted more people in the area thus, straining most of the available public utilities including pipe borne water supply.

\section{MATERIALS AND METHODS}

This study is a descriptive survey aimed at assessing the patterns of pipe borne water supply in the Buea Municipality, challenges and the way forward. To achieve this objective, both quantitative and qualitative data was collected. The quantitative data was used to obtain information such as the perceptions of the population on the distribution, reliability, frequency and availability of pipe borne water supply. Qualitative data also encompassed the observations made on the quality and quantity of water supply and infrastructures like the number of stand taps in the study area. With the view of achieving the objectives of this study, data from primary and secondary sources were used. The primary sources consists of interviews with the individuals and the administration of questionnaires and field observation while secondary data sources consists of published and unpublished information including reports, journals, books, internet and libraries on pipe borne water supply in the various institutions. It was from the background of the study that the study was developed and the areas that needed improvement identified. Questionnaires were administered to the area residents who were selected randomly. For instance, five streets were randomly selected from each zone and five houses were interviewed and the household head present at each time of arrival at each house were interviewed. The design of the questionnaire was such that they met the objectives of the study. Simple random sampling was used to select zones taking into consideration the housing patterns and income levels. Molyko and Federal Quarters were selected from upper and lower Buea respectively in order to assess their patterns of pipe borne water supply in relation to their residential patterns and income differences and one hundred and twenty questionnaire (120) were administer sixty in Molyko and Federal Quarters respectively. Data elicited were analyzed with simple percentages and Wilcoxon Signed Ranks Test. The results were presented using tables and figures.

\section{LITERATURE REVIEW}

This study was designed to explore the patterns of pipe borne water supply, challenges and the way forward in the
Buea Municipality. Consequently, the following are reviewed works in the following sections: patterns of water supply, accessibility, reliability, challenges and the way forward.

Tundis et al.; (2008) indicates that there is an uneven distribution of volumes of water supply and availability in Brazil. Despite the abundance of water resources in the country, estimated at about $14 \%$ of the entire planet's freshwater resources, freshwater supply and provision continue to be a challenge in many metropolitan regions of the country. For example, while the per capita water available for residents in the Amazon metropolitan region is $700,000 \mathrm{~m}^{3}$, residents in São Paulo metropolitan region received only $280 \mathrm{~m}^{3}$.This is grossly inadequate and a major constraints for the region's water demands for social, economic and human health which need high water demand and availability. Hence, restoration of water supply infrastructure and sources, improvement in hygiene, sanitation and sewage treatment, recuperation of water infrastructural systems and of water sources are vital components in meeting the demand for water by different activities especially in one of the largest peripherals metropolitan regions (São Paulo) of Brazil. The importance of potable water in the daily lives of urban residents in Cameroon cities and towns has been noted. According the Ministry of Water Resources and Energy of Cameroon (MINEE, 2012) since the last few decades, the government has intensified its efforts in improving and managing potable water supply infrastructures and sources especially in major urban centers and towns in the country in order to meet the raising demand from population and economic activities. Therefore, the financial allocation in the water supply sector has increased significantly in bit to meet up with this objective both in the long and short terms (MINEE, 2012). The is also in line with the end of year message (2018) of the President of the Republic His Excellency Paul Biya who indicated his intentions towards raising the living conditions of the citizen in the country through the provision of basic services like pipe borne water supply to all. After the Democratic Republic of Congo, Cameroon is second as far as good quantity of available water resources is concerned in Africa, estimated to be three folds the world's average of 7,000 $\mathrm{m}^{3}$ (Ako, Eyong, \&Nkeng, 2009), however, the issue of pipe borne water supply especially reliability, accessibly and quality continue to remains a major problem facing urban planners and managers including the stakeholders in Cameroon. Mismanagement and authorities' inability to understand the patterns of urbanization for effective planning account for these (Mafany \& Fantong, 2006). These situations have left many areas within the cities and 
towns in the country unsaved with adequate water supply. Fonjong and Fokum (2017), opine that peri-urban areas in Cameroon emerge spontaneously due to deficiency in planning and urbanization, and are difficult to delimit. Although their inhabitants are diverse, most are urban poor who cannot afford the cost of living in the city, and rural people who have been engulfed by urban sprawl. According to them, although peri-urbanism may have potentials for urban development and sustainability, the absence of planning leaves its inhabitants with a number of social deprivations like pipe borne water supply, making living and commuting in these areas thoughtprovoking. Ayoade (1975) cited in (Ikelegbe and Okaruwa 2007), indicates that the main challenges to the development of water resources in Nigeria include: haphazard, uncoordinated and irrational national policies. The author indicates that water resources in Nigeria have been chaotic, uncoordinated and above all not based on a sound national policy. These have left each state in the country to implement different water development structures that are usually sub-standard and unconventional with merger financial resources. The authors suggest a holistic and integrated approach to water resource management and planning in Nigeria. According to WWR(2004), there is no potable water crisis today, instead the crisis is not about having too little water to satisfy our need but the crisis is about water management so badly that billions of people especially in developing countries suffer badly. Wyndham (1956) on his part opine that the main reas on behind water shortages in some American cities is water requirements. Water requirement for domestic and industrial purposes to the author have increased significantly since the end of WW2 due to extension of water supply services to large portion of the population. However, increase in demand caused by water using devices like washing machines, dish washing or air conditioning have not yet taken place to a material extent in smaller communities due to limited finance. The main challenges to pipe borne water distribution in Nigeria today is attributed to inadequate planning and mismanagement in order to ensure full coverage of water supply in relation to each community's' demands (Ikelegbe and Okaruwa 2007). Turner et al.; (2011) also indicates that there are several factors which have led the city of Bulawayo in Zambia to experience water problem but the most seemingly overbearing factor had been population increase, increase in the demand for water and drought. The situation has also been worsened by the failure to harness and preserve available water. However, uneven distribution, poor management of water supply and water resources in general are the major causes of water crisis in many areas in developing countries including the Buea Municipality of Cameroon. Therefore, an evaluation of water supply systems and infrastructures continue to be important factors in ensuring that limited water resources availability meet the need of the growing population of the Buea Municipality.

\section{RESULTS AND DISCUSSIONS} The Evolution and Diversified Uses of Pipe-borne Water Supply in the Buea Municipality

Prior to the introduction of pipe-borne water supply in Cameroon and in the Buea Municipality in particular by the colonial masters, the main sources of water for domestic consumption was mainly from rain-fed, nearby springs, streams/rivers and wells. The construction and upgrading of water supply, which included, gravity pipeline and boreholes with head works (as pipe-borne water) for improving the quantity and quality of water, began in the early 1900s by the Germans, then the British in 1920s and the State of West Cameroon in 1960s. Since the 1960s, little was done to improve or rehabilitate the infrastructure left during the colonial and post-colonial eras (The history of water politics and the politics of water history in the Anglophone Cameroon). It was only in 2008 that an additional catchment was developed at small Soppo to augment the water supply whose demand exceeded the rate of supply by the population. More so, 2 billion FCFA in 2012 was donated by the Chinese Government to the Buea Municipal Council for the construction of twenty five (25) boreholes so as to meet up with the increase deficit from the CAMWATER supply in some neighborhoods within the Buea Municipality (Buea Council, 2015). Their distribution involves the treatment of water supplied using chemical and biological substances to enable safe and less turbidity of water for drinking.

The origin of water scarcity in the Molyko neighborhood can be traced right back in the early 1990s just after the creation of the University of Buea in 1993. This was the only Anglo Saxon University in Cameroon and as such influences the influx of many students into this area and this eventually led to population increase and other multiplier effect. Unfortunately, increased in population has not matched the quantity of water supplied to the population over the years by CAMWATER in this neighborhood resulting in the use of alternative water sources like streams and bore holes. Despite the historical evolution of pipe-borne water supply in the study area, the supply of water continue to be a challenge as pipe-borne water is not evenly distributed among the different neighborhoods. While some neighborhoods are over served with pipe-borne water, majority of the neighborhoods are under served. Moreover, the use of 
pipe-borne water supply by households for their domestic, industrial, recreation and agricultural activities turn to be unrivalled from the uses of other sources in the Buea
Municipality. This is clearly evident as indicated by how improved pipe-borne sources usage is unrivalled by $94.2 \%$ as indicated on Fig. 1.

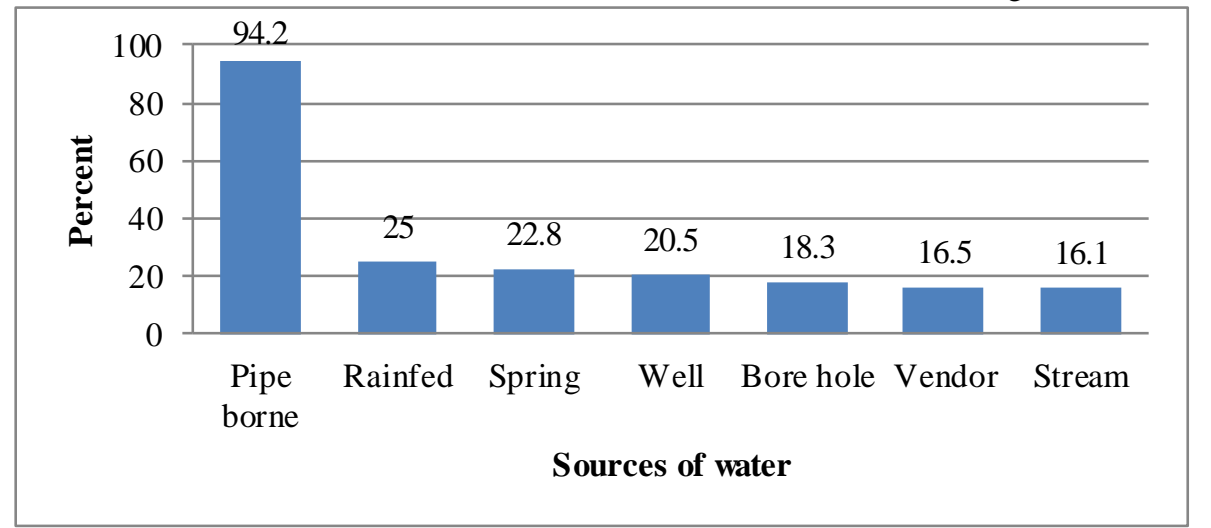

Fig.1: Respondent Views on the Usage of water Sources in the Buea Municipality Source: Field work, 2018

From Fig 1, pipe-borne water is the most water source being used (94.2\%). Over $90 \%$ of the sampled households in the Buea Municipality use pipe-borne water because of its good quality (improved source) unlike other water sources like streams, wells and even springs which are unimproved or polluted. The usage of improved water sources is high in areas of high population and areas void of springs and streams as the case of Molyko neighborhoods and Federal Quarters respectively. The water utility company (CAMWATER) is forced to extend pipe borne water supply to these areas at all cost despite its policy of rationing in order to keep its customers.

Water is a key element of human and dignified life. It is directly or indirectly consumed by humans to sustain their livelihoods and also for their economic improvements. Over the years, water use has become diversified in the Buea Municipality against the back drop of population increase, changing life styles of the people and diversified socio-economic activities. During the colonial period, the Buea Municipality witnessed the introduction of a reservoir tank at the German Spring in the upper section of the town where the colonial masters resided. This reservoir supplied improved water to the population for domestic uses. Due to population pressure and increase in socio-economic activities, there has been the high demand for pipe-borne water for domestic, industrial, commercial, agricultural, recreational and institutional uses.

Despite the water scarcity in the Buea Municipality, typical households in the study area use water for broad range of purposes, from small quantity needed for drinking, cooking and bathing to large quantity needed in cleaning and washing dresses, car washing at home, gardening or watering animals. Moreover, if development is to be sustained, adequate quantity of water most be available and use, in fact as development increase, in most cases, the demand for water will also increase on per capita bases for personal, commercial, agricultural, industrial, institutional and recreational purposes. This has been the case in the study area where increase in socioeconomic activities has resulted to increase in the demand and use of water.The analysis of the field survey on Table 1 , indicated that majority of the households in the sampled neighborhoods in the Buea Municipality use water for domestic uses (50\%), followed by $25 \%$ for industrial uses and the least, $15 \%$ for agricultural uses and $10 \%$ for institutional uses.

Table.1: Diversified Uses of Water in the Buea Municipality

\begin{tabular}{|c|c|}
\hline Uses & Percentage(\%) of Total used \\
\hline Domestic & 50 \\
\hline Industrial & 25 \\
\hline Agricultural & 15 \\
\hline Institutional & 10 \\
\hline Total & 100 \\
\hline
\end{tabular}

Source: Field work, 2018

\section{Patterns of Pipe-borne Water Supply in the Buea Municipality}

This section looks at the patterns of pipe-borne water supply in the Buea Municipality. The quantity of water supply is measured from the statistics obtained from CAMWATER on the quantity of water supplied in the study area as well as from the responses of thepopulation from the questionnaires and interviews. The evolution of water supplied for the two neighborhoods in the study area as indicated on Table 2 reveals that there is an increase in the supply of pipe-borne water in the study area from about $8000 \mathrm{Cu}^{3}$ liters in 2015 to $10000 \mathrm{Cu}^{3}$ in 2016 and $15000 \mathrm{Cu}^{3}$ Litres in 2017. The perpetual increase in the supply of water is due to the 
rehabilitation works carried out in 2013, privatization SNEC and the construction of a new surface water catchment at Small Soppo which increases the quantity of water supply considerably despite the high demand from population increase and economic activities in these neighborhoods.

Table.2: Evolution of Water Supply in the Selected Neighborhoods in the Buea Municipality (2015-2017)

\begin{tabular}{|c|c|c|c|}
\hline $\begin{array}{c}\text { Buea } \\
\text { Municipality }\end{array}$ & \multicolumn{3}{|c|}{ Year } \\
\hline Water Supply & 2015 & 2016 & 2017 \\
& $\mathrm{Cu}^{3}$ & $\mathrm{Cu}^{3}$ & $\mathrm{Cu}^{3}$ \\
& Liters & Liters & Liters \\
\cline { 2 - 4 } & 8000 & 10000 & 15000 \\
\hline
\end{tabular}

\section{Source: CAMWATER, 2018}

Unfortunately, the increased population of the study area over the last decades has not matched the quantity of water supplied in the two neighborhoods over the years by CAMWATER. Majority of the residents of Molyko (more than 90\%) of the population of the neighborhood do not have access to taps/pipe borne water on daily basis as against 69\% for Federal Quarters, causing the people to cover long distances to fetch water from other neighborhoods, streams or rivers to compensate their shortage. Water shortage in Molyko is due to poor water rationing and degradation. For instance, in the Native Fence Street of Molyko neighborhood commonly called "Malingo Street", water flow only for 4 to 5 times in a week even though the number of flow times in not constant at times, water flow just for about 5 hours on the day water is supplied and this prevent many people from fetching the quantity of water they require for their different needs. Sometimes, even 5 hours are not of a sustained, the water could flow for 2 hours, cease and flow again for 1 hour 30 minutes and ceases before flowing again for 1 hour 30 minutes. This variation increases the number of times people have to wait in order to fetch a satisfactory quantity of water.Even those with private connections in the two neighborhoods complain that, the water no longer flows in their houses. As such majority of them fetch water from alternative sources or buy water from vendors on a daily bases. Moreover, there is little or no maintenance of public taps in most cases. Hence, the number of public taps has decrease over the years in the selected neighborhoods in the study area due to poor management. The situation has been worsening by the fact that over $48 \%$ of the population depends on public taps alone in the Buea Municipality for their pipe borne water supply. As a result, frequent fighting and quarrelling abounds this led to the destruction of stand taps. Table 3 shows the trends in the number of stand pipe in the selected neighborhoods.

Table.3: Trends in the Number of Functional Stand Taps in the Selected Neighborhoods

\begin{tabular}{|l|c|c|c|}
\hline Neighborhoods & $\mathbf{2 0 0 0}$ & $\mathbf{2 0 0 5}$ & $\mathbf{2 0 1 7}$ \\
\hline Molyko & 10 & 5 & 7 \\
\hline Federal Quarter & 3 & 0 & 2 \\
\hline Total & 13 & 5 & 9 \\
\hline
\end{tabular}

Buea Council (2008)

From Table 3, the number of functional stand pipe in the selected neighborhoods has reduced significantly over the years from 10 and 3 in 2000 in Molyko and Federal Quarters to5 and 0 in 2005 and 7 and 2 in 2017 in Molyko and Federal Quarters respectively. The average number of person per stand tap has decreased drastically over this periods and this has increase the pressure on the limited pipe borne water supply infrastructures as well as forced some of the population to fetch water from alternative sources which are doubtful to their health. The average number of person per stand post in the selected neighborhoods is presented on Table 4.

Table.4: Average Number of Person per stand Pipe in the Selected Neighborhood

\begin{tabular}{|l|c|c|c|c|c|c|}
\hline \multirow{2}{*}{ Periods } & \multicolumn{2}{|c|}{ Population } & \multicolumn{2}{c|}{$\mathbf{N}^{\mathbf{2}}$ of stand taps } & \multicolumn{2}{c|}{ Average person/stand tap } \\
\cline { 2 - 7 } & Molyko & $\begin{array}{c}\text { Federal } \\
\text { Quarters }\end{array}$ & Molyko & $\begin{array}{c}\text { Federal } \\
\text { Quarters }\end{array}$ & Molyko & $\begin{array}{c}\text { Federal } \\
\text { Quarters }\end{array}$ \\
\hline $\mathbf{2 0 0 0}$ & 11,000 & 1,313 & 10 & 3 & 1,100 & 4,38 \\
\hline $\mathbf{2 0 0 5}$ & 13,864 & 3,093 & 5 & 0 & 2,777 & 3,092 \\
\hline $\mathbf{2 0 1 7}$ & 22,000 & 6,329 & 7 & 2 & 3,143 & 3,166 \\
\hline
\end{tabular}

Source: Buea Council and Field Work, 2018

From Table 4, there is a clear indication that the average number of person per stand tap in the selected neighborhoods has increased from 1,100 and 4,38persons per stand tap in 2000 to 2,777 and 3,092 in 2005 and to 3,143 and 3,166 persons per stand tap in the two neighborhood respectively in 2017. This increase however, does not march with the increase in population growth of the selected neighborhoods because of high rate of congestion of people experience at water points like commercial bore holes especially in Molyko. This has 
force the inhabitants to search for more accessible and reliable sources such as wells and bore holes or buy from vendors.

Table.5: Respondent Accessibility to Various Types of Pipe-borne Water Supply in the Selected Neighborhoods in the Buea Municipality

\begin{tabular}{|l|c|c|}
\hline \multicolumn{1}{|c|}{ Type of Access } & Molyko & $\begin{array}{c}\text { Federal } \\
\text { Quarters }\end{array}$ \\
\hline House connection & $32(74 \%)$ & $39(81 \%)$ \\
\hline Public Standpoint & $6(14 \%)$ & $1(2 \%)$ \\
\hline Boreholes & $4(9.3 \%)$ & - \\
\hline Wells & $1(2.33 \%)$ & - \\
\hline Spring/Stream/Others & - & $8(17 \%)$ \\
\hline Total & 43 & 48 \\
\hline
\end{tabular}

Source: Field work, 2018

The uninterrupted streams of drinkable (fresh) water that flow from the urban consumer faucet, water connections or taps are message of warnings to the different stakeholders including the council, government and CAMWATER on how the local inhabitants recognize the reliability of water supply in the Buea Municipality. Consumers and costumers in the Buea Municipality preserve the inadequacy of water supply as the absent of reliable water supply to the community. In either case, water supply reliability has become an expected part of urban existentialism and people are getting more and more use to it. Water supply reliability is a complex term that either refers to shortages that result from failure of physical components of water supply systems or the likelihood that a systemsuch as water supply system does not fail, or conversely or better still it is the likelihood of a system failure subtracted from one that fails (Hawk, 2003). Whatever the case, all systems including water supply break down, and they do so for some reasons be itfundamental inadequacy, natural and anthropogenic causes like floods and population growth which raises the water supply infrastructures and sources demand above their capacity (Hawk, 2003). The unreliability of pipeborne water supply is evident and common in the Buea Municipality. An analysis of respondent's views of the reliability of the pipe-borne water supply shows thatthe frequent failures in supplies tend to be higher in Molyko (34\%) than in Federal Quarter(26\%) as indicated on Table 6.

Table.6: Perception of Respondents on the Reliability of Water Supply in the Selected Neighborhoods in the Buea Municipality

\begin{tabular}{|l|c|c|}
\hline Response & Molyko & $\begin{array}{c}\text { Federal } \\
\text { Quarter }\end{array}$ \\
\hline Never Fails & $3(4 \%)$ & $4(9 \%)$ \\
\hline Fails occasionally & $25(58 \%)$ & $20(20 \%)$ \\
\hline Fails frequently & $15(34 \%)$ & $13(26 \%)$ \\
\hline Never flows & $2(4 \%)$ & $8(17 \%)$ \\
\hline Not applicable & - & $3(6.25 \%)$ \\
\hline Total & 43 & 48 \\
\hline
\end{tabular}

Source: Field work, 2018

Unreliability of pipe-borne water supply often than not forces the urban households in the Buea Municipality to depend on other alternative water sources like bore holes, wells, springs and streams. Analysis of findings on the perception of pipe borne water supply reliability in the selected neighborhoods indicated (Table 6) above shows that residential pipe borne water supplies are mostly achieve through the use of alternatives water sources as indicated on Table 7. However, the use of wells and boreholes as alternative water sources to supplement improved pipe borne water supply is uncommon in Federal Quarter, unlike what obtains in Molyko due to the topographical characteristics of the area in terms of geology, soil and relief. The area has scracious rock particles, steep relief which does not favour infiltration but rather facilitate runoff after downpours. This tends to limit the amount of underground water supply. The populations continually use these water sources in order to meet up with their daily needs in terms of domestic, industrial and commercial, agricultural, institutional and recreational uses.

Table.7: Alternative Sources of Water Supply by Respondents in the Buea Municipality

\begin{tabular}{|l|l|l|}
\hline Alternative Sources & Molyko & $\begin{array}{l}\text { Federal } \\
\text { Quarter }\end{array}$ \\
\hline Storage tanks & $10(16 \%)$ & $14(23 \%)$ \\
\hline Wells & $2(4 \%)$ & - \\
\hline Water vendor & $11(18 \%)$ & $8(18 \%)$ \\
\hline Boreholes & $35(58 \%)$ & - \\
\hline Not Applicable & $2(3 \%)$ & $32(69 \%)$ \\
\hline Total & 60 & 54 \\
\hline
\end{tabular}

Source: Field work, 2018

The increase in the number of standards housing has also been very remarkable in the construction of multiple story or floors with water demand and use amenities like showers, flush water systems and birth tubs, dish washing, gardening and car washing in the study area. $75 \%$ of the story building in the Buea Municipality is built in the last two decades with majority in Molyko because of high demand for student hostels and hotels. 
Inhabitants who live in standard houses pay more water builds than those living in sub-standard houses void of water systems facilities like showers and flush toilets or washing machines. The inhabitants of such houses depend on water from public taps located outside their premises or buy water from vendors. The consumption patterns in relation to bills paid in the two neighborhoods in the study area is indicated on Table 8 shows that majority of bills are paid by residents in Molyko $31 \%$ than in Federal Quarters 23\% for those who pay between 1-5000 FCFA.

Table.8: Consumption Patterns in Relation to Bills in the Selected Neighborhoods in the Buea Municipality

\begin{tabular}{|l|c|c|c|c|}
\hline $\begin{array}{c}\text { Neighborhood/Amount Paid } \\
\text { (FCFA) }\end{array}$ & $\begin{array}{c}\mathbf{1 - 5 , 0 0 0} \\
(\mathbf{\%})\end{array}$ & $\begin{array}{c}\mathbf{6 - 1 0 , 0 0 0} \\
(\boldsymbol{\%})\end{array}$ & $\begin{array}{c}\mathbf{1 1 - 1 5 , 0 0 0} \\
(\boldsymbol{\%})\end{array}$ & $\begin{array}{c}\mathbf{1 6 , 0 0 0 \pm} \\
(\boldsymbol{\%})\end{array}$ \\
\hline Molyko & 31 & 16 & 9 & 20 \\
\hline Federal Quarter & 23 & 14 & 10 & 12 \\
\hline Total & 54 & 30 & 19 & 32 \\
\hline
\end{tabular}

\section{Source: Field work, 2018}

Furthermore, majority of the households in the Buea Municipality because of unreliability of pipe-borne water supply are forced to buy water from vendors in order to meet with their daily demands. Vendors are individuals involve in the sale of water to the population that are without access to pipe-borne water supply in the different neighborhoods. It is not a type of water source as misconceived by people, but rather as an agent of water supply. This activity is increasingly becoming an important part of the daily life of some individuals in the Buea Municipality especially those who cannot be employed in other income generating activities as well as school dropouts. As indicated on Table 9, majority of the respondents in Molyko purchase more water per day (38\%), unlike the households in Federal Quarterwho purchase less amount of water per day (33.33\%).

Table.9: Purchase of Water by Households per day in the Selected Neighbourhoods in the Buea Municipality

\begin{tabular}{|l|c|c|}
\hline $\begin{array}{l}\text { Number of 20 Liter } \\
\text { Jerry cans }\end{array}$ & Molyko & $\begin{array}{l}\text { Federal } \\
\text { Quarter }\end{array}$ \\
\hline $1-3$ & $19(38 \%)$ & $6(33.33 \%)$ \\
\hline $4-6$ & $16(32 \%)$ & $8(44.45 \%)$ \\
\hline $7-9$ & $8(16 \%)$ & $2(11.11 \%)$ \\
\hline 10 and Above & $6(12 \%)$ & $2(11.11 \%)$ \\
\hline Not Applicable & $1(2 \%)$ & - \\
\hline Total & 50 & 18 \\
\hline
\end{tabular}

Source: Field work, 2018

Moreover, the reliability of water supply by CAMWATER is highly inadequate and ineffective. Analysis indicates that only $10 \%$ and $5 \%$ of the sample residents in Molyko and Federal Quarters respectively indicate that water never flows. The rest of the sampled population indicates that water either water does not flow occasionally, frequently or it never flows at all as indicated on Table 10. These variations in the reliability of water supply show a high variation of unreliability by CAMWATER in meeting the needs of the population of the study area. The study also determined the seasonal variability of water supply in the study area. The results indicated that there is unreliability of water supply in the dry and rainy reason as represented by $6 \%$ and $10 \%$ of respondents view in Molyko and Federal Quarters respectively.

Table.10: Respondents Views on the Reliability of Pipeborne Water Supply in the Selected Zones in the Buea

\begin{tabular}{|l|c|c|}
\hline Response & Molyko & $\begin{array}{c}\text { Federal } \\
\text { Quarter }\end{array}$ \\
\hline Never Fails & $2(5 \%)$ & $5(10 \%)$ \\
\hline Fails occasionally & $25(58 \%)$ & $20(20 \%)$ \\
\hline Fails frequently & $14(33 \%)$ & $12(25 \%)$ \\
\hline Never flows & $2(4 \%)$ & $8(17 \%)$ \\
\hline Not applicable & - & $3(6.25 \%)$ \\
\hline Total & 43 & 48 \\
\hline
\end{tabular}

Source: Field work, 2018

Some parts of Molyko and Federal Quarters experience the absent of water flow in the dry season. However, irregular flow of water is more common in Federal Quarters as indicated on Table 11.

Table.11: Respondents Views on the Seasonal Variability of Pipe-borne Water in the Selected Neighboods in the Buea Municipality

\begin{tabular}{|l|l|l|}
\hline & Rainy Season & Dry Season \\
\hline
\end{tabular}




\begin{tabular}{|l|c|c|c|c|}
\hline Reliability of water supply & Molyko & $\begin{array}{l}\text { Federal } \\
\text { Quarter }\end{array}$ & Molyko & $\begin{array}{c}\text { Federal } \\
\text { Quarter }\end{array}$ \\
\hline Regular & $9(21 \%)$ & $36(75 \%)$ & $7(16 \%)$ & $30(61 \%)$ \\
\hline Irregular & $32(75 \%)$ & $4(8 \%)$ & $31(72 \%)$ & $13(28 \%)$ \\
\hline Never Flows & $1(2 \%)$ & $3(6 \%)$ & $5(12 \%)$ & $5(10 \%)$ \\
\hline Unable to Connect & $1(2 \%)$ & $5(10 \%)$ & - & 48 \\
\hline Total & 43 & 48 & 43 & \\
\hline
\end{tabular}

Source: Field work, 2018

To further illustrate the unreliability of pipe-borne water supply in the Buea municipality, water supply data were obtained or collected from the Ministry of Water Resources and Energy MINEE (2018). The data indicated that, the unreliability of water supply in 2015 at the level of the German spring was catastrophic, whereby the per capita supply per day of $3000 \mathrm{~m}^{3}$ during the rainy season reduced from $650 \mathrm{~m}^{3}$ per day to $200 \mathrm{~m}^{3} /$ day during the dry season as a result of rainfall variability as illustrated on Table 12. The situation in April 2015 was so severe that the production of water was halted as any attempt to supply water to the population of the town would have resulted to the drying off of the water table and water in the reservoir tank. This seasonal fluctuation of water supply or unreliability situations impacted severely on the population living around the Mosole catchment with Federal Quarter inclusive.

Table.12: Variation in daily water production in the rainy and dry seasons at the level of German Spring in 2014 2015

\begin{tabular}{|l|c|c|c|}
\hline Month & Year & $\begin{array}{c}\text { Daily Water } \\
\text { Production } \\
\left(\mathbf{m}^{\mathbf{3}}\right) / \text { day }\end{array}$ & $\begin{array}{c}\text { Drop in Daily } \\
\text { Water } \\
\text { Production } \\
\left(\mathbf{m}^{\mathbf{3}}\right) / \text { day }\end{array}$ \\
\hline March & 2014 & 3000 & 700 \\
\hline March & 2015 & 3000 & 600 \\
\hline April & 2015 & 3000 & 100 \\
\hline
\end{tabular}

Source: MINEE, 2018

The population growth statistics was correlated with the water supply statistics for the respective years in the different neighborhoods of the study. The results reveal that there is a fluctuation in the level of water consumption per capita as a result of population growth and fluctuation in water supply due to inadequate water management by the water supply authorities. The amount of water consumption by the population per capita in 2015, 2016 and 2017 is decreasing rapidly due to population increase and fluctuation in water supply due to inadequate management by the water supply authorities with very little initiative to address the situation. These figures show that the increase in water supply especially in 2012 following the president visit in which a new catchment at Small Soppo was established to augment water supply has not been able to match with the increased demand for by the population. The actual demand for water per household was on at average of 35.085 Liters/day (95\% CI: 28.587-42.400), significantly (Wilcoxon Signed Ranks Test: $\mathrm{Z}=-7.480$; $\mathrm{P}<0.001$ ) higher than what was effectively consumed which average was 27.506 Litres/day (95\% CI: 24.060-35.668), therefore implying that the demand was not really met as indicated on Table 13.

Table.13: Perceived water consumed and demanded per household in the Selected Zones in the Buea Municipality

\begin{tabular}{|c|c|c|}
\hline Statistics & $\begin{array}{c}\text { Average water } \\
\text { consumed per } \\
\text { household per } \\
\text { day }\end{array}$ & $\begin{array}{c}\text { Average water } \\
\text { demand per } \\
\text { household per day }\end{array}$ \\
\hline $\mathrm{N}$ & 223 & 182 \\
\hline Mean & $\begin{array}{c}27.506 \\
(24.060-35.668)\end{array}$ & $\begin{array}{c}35.085 \\
(28.587-42.400) \\
\end{array}$ \\
\hline Median & 20.0000 & 25.0000 \\
\hline $\begin{array}{c}\text { Std. } \\
\text { Deviation }\end{array}$ & 35.79497 & 46.55477 \\
\hline Minimum & 5.00 & 0.17 \\
\hline Maximum & 500.00 & 600.00 \\
\hline
\end{tabular}

The actual water demand per household as well as actual water consumption average indicated on Table 13 are all less than the required standards of 40 liters per capita per day recommended for urban residents by the (UN, 1992). The population has to resort to other alternative water sources in order to meet their urban water demand.

Problems of Pipe-borne Water Supply in the Buea Municipality

To fine out residential perception of the challenges of pipe (fresh) water supply in the Buea Municipality, respondents were initially asked if they experience water supply challenges. The result shows that $72.8 \%$ and $70 \%$ responded to the affirmative, while $27.2 \%$ and $30 \%$ said they do not experience any challenges of water supply in the two 
neighborhoods of the study area. This indicate that there are challenges as far as water supply situations are concern in the Buea Municipality as evidence by poor water management, leakage of pipes and so on are concern.

Several challenges therefore accrue to the water supply situation in the Buea Municipality. These include both physical and anthropogenic factors ranging from inadequate water supply, leakage of pipes and mismanagement by appropriate authority and lack of government intervention. It is therefore, difficult to derive a definitive explanation for the problems of water supply in the town over the past decades. In some neighborhoods for instance, the main challenge to water supply result from poor management of urban infrastructures by the stakeholders; in others factors such as increase in inadequate water supply and leakages of pipes are the main challenge to water supply. Based on multiple response opinions from the questionnaire indicates the shortfall in water supplies to leakage of pipes as indicated by $7 \%$ in Molyko and 15\% in Federal Quarter, mismanagement by appropriate authority is indicated by $25 \%$ in Molyko as against $18 \%$ in Federal Quarter, lack of government intervention $43 \%$ in Molyko as against $30 \%$ in Federal Quarter and inadequacy in the availability of water as indicated by $25 \%$ in Molyko as against $11 \%$ in Federal Quarter as indicated on Table 14.

Table.14: Respondents Opinions on the Causes of Shortfall in Water Supply in the Selected Neighborhoods in the Buea Municipality

\begin{tabular}{|l|l|l|}
\hline $\begin{array}{l}\text { Causes of Shortfall in Water } \\
\text { Supply }\end{array}$ & Molyko & $\begin{array}{l}\text { Federal } \\
\text { Quarter }\end{array}$ \\
\hline Leakage of pipes & $4(7 \%)$ & $8(15 \%)$ \\
\hline $\begin{array}{l}\text { Mismanagement by } \\
\text { Authorities }\end{array}$ & $15(25 \%)$ & $10(18 \%)$ \\
\hline $\begin{array}{l}\text { Lack of Government } \\
\text { Intervention }\end{array}$ & $26(43 \%)$ & $30(56 \%)$ \\
\hline $\begin{array}{l}\text { Inadequate availability of } \\
\text { water supply }\end{array}$ & $15(25 \%)$ & $6(11 \%)$ \\
\hline Total & 100 & 100 \\
\hline
\end{tabular}

Source: Field work, 2018

The ineffectiveness in the supply of pipe-borne water supply has been adduced to certain factors affecting the local population in the study area such as the following:

There is a limited amount of money allocated to the provision of water supply and maintenance of infrastructures in the municipal council budgetary allocations and even in the country as a whole as compared to other sectors despite the increasing urgency and reiteration by government authorities and the president of the Republic His Excellency President Paul Biyato increase the number of people with access to adequate water supply and sanitation in rural and urban areas in order to increase the living standards of Cameroonians.

There is limited or no of up-to record on population growth rate, operational economic activities, water demand and supply, water quality standards and land use land use change that could contribute to sustainable water management in urban planning in urban centers. Since water management enhancement is directly or indirectly related to these indicators. Successes or failure in them also affects water management.

There is absent of a sound of organization structure at the same and different levels of government as far as the management of water supply in the Buea Municipality is concern. The stakeholders including the council, the government and CAMWATER do not carry out their supervision and maintenance functions in water supply effectively and efficiently due to the absent of adequate finance, cooperation and collaboration in decision making processes, partnership between different department of the same institutions and different institutions as well as setting up standards for water management and supervising the private water vendors, private borehole and community water schemes that augment water supplies in the town. There is also the lack of cooperation between different department and institutions. For instance, collaboration between the energy supply company ENEO and CAMWATER is very timid and week. This has affected the water supply and production in the study area significantly especially during the dry season in many areas as the water authorities have to stop water production of do water rationing.

Poor management of water supply is also noticeable in situations where authorities misuse funds located for water projects or for rehabilitation. Some people pay money for water supply but yet, they do not have water or it takes a long time before they are being connected. When such inconveniences occur, they are forced to go for weeks or even more without adequate water supply.

Most of the water supply infrastructures are out-of-date and absolute due to lack maintenance, negligence, limited finance, insufficient trained officials, electricity failures and irregular checks of equipment and replacement. This is the case with the water supply tank for the whole town which has remained unchanged since its establishment by the Germans during the colonial periods while population increase has continued to exert pressure on this unexpanded source of water supply. The negative effect of poor water infrastructure include: linkages of pipes and water contamination from rust pipes and infiltration of dirt and polluted substances through joints into the waterwhich not only affect the health of the population 
but also result to high operational cost and expenditure. In situations where breakage occurs on the main pipe that channels water to other neighborhoods, it leads to unreliability in the supply of water in the affected neighborhood especially with delays in repairs which take weeks or months.

Inadequate finance by the government and municipal authorities limits the extension of water supply networks to peri urban areas and new layouts in the Buea Municipally. It's also limits the development of new catchment areas, alternative water sources like bore holes and springs as well as the procurement of equipment and employment of trained personnel. Limited finance of water supply infrastructure in the study area is also attributed to the failure of consumers to pay for water they consumed because of over rating of their consumption units as well as the nonpayment for water at public taps. The population of the Buea Municipality considers water as a free rider unlike their counterpart in others cities and towns Douala, Yaoundé and Bamenda where the urban population pays for water at public stand taps.

Geological factors including relief, soils and drainage have contributed to ineffective water supply distribution in the study area. Empirical evidences by Lambi and Kometa (2009) and Baba (2016) for instance shows that in the Buea Municipality, the geological structure of the underlying rocks are very poor in forming good aquifers for water supply especially in the upper section of the town. This means that the groundwater reservoirs are found at great depth in upper part of Buea including Federal Quarter areas but shallow in others including Molyko, thereby making the harnessing and supply of groundwater an enormous task.

Rapid urbanization process within Buea has led to the destruction of natural vegetation. Many paved surfaces have been realized thereby restricting the normal circulation of the hydrological cycle. Also, there has been massive construction of settlements for human habitation. This has destroyed the natural vegetation; exposing watersheds which automatically lead to intense solar radiation especially during the dry season. This has led to water sources drying off while others like wells and springs has noticed a drastic drop in their volumes as was confirmed by field observations in Federal Quarters and Molyko.

The failure by stakeholders especially policy makers to plan, fund, and manage mechanisms to deliver water in proportion with the rate of urban growth represented one of the most serious threats to the future of sustainable development in the Buea Municipality. The town had also been expanding with the southern section of the town having high density in terms of population growth and socio-economic activities such as the construction of modern structures and businesses (Bea Council, 2008). Neighborhoods such as Molyko, has become one of the fastest growing neighborhoods in the town. This massive rate of population growth and rapid urbanization are the epitome of the water supply problems that the town is facing today. This explained why water scarcity were being felt more in high density neighborhoods in the southern sections of the town (Molyko-30,000 inhabitance) than northern sub section of the town (Federal Quarter) because of population density.

The pollution of streams resulting from sewage, fertilizers, chemicals and solid waste materials from households, industrial and agricultural activities are an increasing threat to water sources in the Buea Municipality. The inhabitants attested to the fact, most of the streams such as River Ndongo and Mosole are no longer suitable for drinking or for domestic use. This claim was verified through field observations. It was found that most of the stream courses were littered with solid and household waste which reduces the reliability of these streams to the population for water need and more importantly some individuals use them as bathing and faucal sides.

\section{CONCLUSION AND RECOMMENDATIONS}

Water is the most important natural resource whose supply, distribution, quality, quantity and management influence the rate of socio-economic development of any community and their livelihoods. The inadequate and poor distribution of water in the Buea Municipality is attributed to degradation of sources, population increase and poor management which has triggered the spread of diseases as well as increase distance to water source and cost. It has also handicapped the economic sector of the Buea Municipality thus, greatly reducing the general standard of living of the inhabitants. As the pace of urban development aggrandize, the growth of the urban environment is imminent. This growth, along with the associated pressures on local populations, increase urbanization and poor management among others will continue to introduce a number of challenges with respect to the provision of water supply to the population both now and into the future. Despite the considerable attention paid to water demand and use over the years, inadequate water supply remains one of the major challenges to the population in the Buea Municipality. From the foregoing therefore, the paper suggests the way forward:

The Government should spell out pliantly, a water management strategy that will be holistic involving all actors and stakeholders including the local community. The strategy should cover all aspects of water demand and supply management as well as infrastructures. For instance, all 
stakeholders including the NGOs, the local council, government and the local community should be actively involved in decision making process as well as participate in the management of water supply in the study area.

Municipal authorities should ensure that water supply by various actors complement each other. Community water schemes should be encouraged through subsidies to such communities. The number of public stand pipes and private water connections should be increased and more proximal to neighborhoods to avoid a situation of congestion at the few available pipes during periods of prolonged water cuts. Also the CAMWATER water storage tanks and reservoirs should be increased to store more water for the growing population of the Buea Municipality as well as the extension of water supply infrastructure to new settlements.

The municipal authorities should ensure that there is effective controlled of private water providers and those who utilized water sources for industrial, domestic and agricultural uses through control of water quality standards, location specification and activities, regularization, standard charges to consumers or costumers and payment of royalties, subsidies and taxes.

Pipes should always be monitored and in case of leakages, the population should immediately report to the authority to resolve the problem. More so, pipes should be laid right deep into the ground so that vehicles and other activities like grading of roads should not get to the pipes and burst them. Government, the municipal authorities and stakeholders should make an assessment of population growth, water needs and demand as well as water quality standards so as to be able to make projection in the future, the water needs and requirement of the population and the different economic activities in the study area. Moreover, the water supply sources and infrastructures need to be upgraded in order to the growing need of the population today and in the future.

The use of rainwater harvesting can be introduced by stakeholders to augment pipe-borne water supply through reservoirs which will hold back huge volumes of water during the rainy season which could be treated and released for use by other activities in periods of scarcity. Moreover, catchment restoration could also be done through reafforestation scheme. The government should ensure effective management of water supply in the Buea Municipality in order to reduce the stress from the people from using alternative water sources in order to reduce the rate of water borne disease which affects the population.

The population should also be educated on the different water demand management practices such as water conservation, reuse so as to minimize the wasteful us of water. Moreover, education should be at all levels of the community where by water managers are prepared with new approaches and skills necessary for the development for water resources management in the $21^{\text {st }}$ Century.

Agricultural activities around water bodies should be monitored and controlled to prevent chemical seepage and other farming activities which take place around catchment points to infiltrate into the water sources and exposed water sources should be limited. Similarly, solutions to water supply challenges in the Buea Municipality should target the is sue of developing new catchments, harnessing new sources of water and enhancing catchment rehabilitation so as to increase the volume of water needed to supply the entire population.

\section{REFERENCES}

[1] Baba, A. (2016). Changing Trends in Water Use in the Buea Municipality, South West Region of Cameroon, Faculty of Social and Management Sciences, University of Buea, Unpublished MSc. Thesis in Geography.

[2] Ako, A., G.Eyong, and G.N keng.(2009). Water Resources Management and Integrated Water Resources Management in Cameroon. Water Resources Management 24 (5):871-88. doi:10.1007/s 11269-0099476-4

[3] Amofah, G.K. (2001): The Role of Water in Health: The Public Concern for Improved Water Supply. An address delivered at a Public Forum on Water Privatization Process. Accra, Ghana.

[4] Andraw,A.A, Jun,S., Eyong, G.E.T. and Fontong, W.Y (2010). Access to Portable Water and Sanitation in Cameroon within the Context of Millennium Development Goals (MDGs).watersctechnol https:doiorg/1/21666/wst.2010.836

[5] Ayoade, J.O and Oyebande B.L. (1978). Water Resources: In Ogontoyibo J. S. (Eds): A Geography of Nigerian Development, Ibadan, Heineman Publishers. Pp. 41 - 56.

[6] Baba, A. and Humphrey. N. N. (2017). Changing Trends in Water Sources and Related Pathologies in Small to Medium Size African Cities. Geo Journal, Volume 83, Issue 4 P 8855-896. link.springer.com (Accessed May, 2019).

[7] Balgah, S. N. (2007): Population Growth-Land Use Dynamics inBuea Urban Area, Loyola Journal of Social Sciences, Jan-July 2009, Vol. 21, No 1.

[8] BUCREP, (2005). Troisieme Recensements General de Population et de l'Habitat. Rapport de Presentation des Resultats Definitifs. Bureau Central des Recensements et des Etudes dePopulation; 66 pp.

[9] Buea Council, (2008). Gestion de l'eau de la commune de BUEA. Rapport de L'amission ECTI de Juin 2008.

[10] Courade, G. (1970). Geography of Cameroon. First Eition, Bamenda, Cameroon. NAB Ventures. 
[11] European Commission (2002). Water is Life Water Framework Directive.

http:ec.europe.eu/environment/water/waterframework/p df/wateris life-en pdf (Accessed February, 2018)

[12]FAO (2007).Coping with Water Scarcity: Challenges of the Twenty - First Century UN - Water.

[13]Fonjong, L. \& Fokum, V. (2017) Water Crisis and Options for Effective Water Provision in Urban and Peri-Urban Areas in Cameroon. Society and Natural Resources, Volume 30, Is sue 4 (2017), pp, 488-505.*

[14] Glieck, P. H. (2000). The World Water, 2000-2001. The Biennal Report on Freshwater Ressources in the World.

[15] Hawk, D (2003).Water Supply Reliability. Draft File. Sciencecalwater.ca.org (Accessed in May, 2019)

[16] Ikelegbe, O and Okuruwa, O.A. (2007'.Meeting the Demand for Pipe borne Water Supply in an Urban Environment: The case of Benin City.Conference Paper.www.researchgate.net (Accessed in May, 2019).

[17] Kedia. A.C. (2015): Remote Sensing Unit, Faculty of Science, Department of Geology, University of Buea.

[18] Kimengsi, J. N., Gwan, S. A \&Elinge L. E (2016).Buea: Cameroon and the Planning Challenges of Peri-Urban Settlements. UGEC View Points (Accessed in March, 2016).

[19] Lambi, C., .M. \& Kometa, S.S. (2009): An Evaluation of Water Resources on the Eastern Slopes of Mount Cameroon, Journal of Human Ecology; 28(1): 47-55.

[20] Mafany, G. T., \& Fantong, W. Y. (2006).Groundwater Quality in Cameroon and its Vulnerability to Pollution. https//www.taylorfrancis.com

[21] Mayo, K (2011). Privatization of commons. Water as a Right. Water is a Commodity. Estelle Bosch Law Review 22(3), 804/822

[22] Mbua, L. (2013). Water Supply in Buea, Cameroon: Analysis and the Possibility for Rainwater Harvesting to Stabilize the Water Demand. Branddenburgischen Technischen, Universitat Cottbus-Senftenberg, Senftenberg, Germany

[23] Meteo.com (2013).The Climate of Buea. http/www.meteocom. (Accessed in December 2013).

[24] Ministère de l'Energie et de l'Eau. (2012). Plan d'action national de gestion inte 'gre 'e des ressources en eau (PANGIRE): Etat des lieux du secteur eau et environnement.

[25] Ministère de l'Energie et de l'Eau. (2018). Plan d'action national de gestion inte 'gre 'e des ressources en eau (PANGIRE): Etat des lieux du secteur eau et environnement.

[26] Mofor, S. (2011): Buea Municipality and Leakage CDE Pipe, RECORDER News Line 23 ${ }^{\text {rd }}$ March, 2011. Http://thestaronlinneinfos/?p316 (Assessed May, 2017).
[27] Page, B. (1989): The History of Water Politics and the Politics of Water History in the Anglophone Cameroon.

[28] Pastore, M. C. (2015). Reworking the relationship between sanitation and the city of Dar es Salam, Tanzania. Environment and Urbanization. IIED, Volume 27(2) 473-488. www.sagepublications.com (Accessed, May, 2019)

[29] Rogers, P. P. et al. (2006) (ed.) Water Crisis: Myth or Reality? London: Foundation Marcelino Botín, Taylor\& Francis,. 331p.

[30] Rogers,P., and A. Hall (2003). Effective water governance: governing without government. Political Studies $\quad 54: 652-67 \quad$ doi:10.1111/j.14679248.1996.tb01747.x

[31] Tundsil, J. G. (2008); Matsu Mu Ra-tundisl, t. limnologia. São Paulo: ofcina de textos, 2008. 631p.

[32] Turner K., Georgiou S., Clark, R. \& Bweker, S. (2004). Economic Evaluation of Water Resources in Agriculture. From the Sectorial to Functional Perspectives of Natural Resource Management, FAO paper Report, No 27 Rome Italy.

[33] UN, (1992): Global Water Partnership: The Concept of Sustainable Water Resources Management (Accessed in December, 2018).

[34] World Water Vision Report (2004). The Economics of Waste Water use in Agriculture. http://www.cwp.org (Accessed in March, 2014).

[35] Wyndham, J.R. (1956). Illinois Municipal Review: The Voice of Illinois Municipalities. 89. http://www.water.usgs/watuse.(Retrived in April 2014). 